\title{
SURFACE TEMPERATURE OF PIGLETS IN CREEP FREEDERS SUBMITTED TO DIFFERENT HEATING SYSTEMS
}

Flavio Alves Damasceno ${ }^{1}$, Carlos Eduardo Alves Oliveira ${ }^{1}$, Jairo Alexander Osorio Saraz ${ }^{2}$, Leonardo Schiassi ${ }^{1}$, Patrícia Ferreira Ponciano Ferraz ${ }^{1}$, João Antonio Costa do Nascimento ${ }^{1}$

\footnotetext{
${ }^{1}$ Universidade Federal de Lavras. E-mail: flavio.damasceno@deg.ufla.br; carlos.oliveira@engagricola.ufla.br; leonardo.schiassi@deg.ufla.br; patricia.ponciano@deg.ufla.br; jacostadonascimento@gmail.com

${ }^{2}$ Universidad Nacional da Colômbia, Medellín. E-mail: aosorio@unal.edu.co
}

\begin{abstract}
The objective of this study was to evaluate the well-being and surface temperature of piglets submitted to different heating systems in creep feeders during the first three weeks of life, using infrared thermography. This work was carried out in a swine maternity of the Experimental Center on the Swine Industry of the Federal University of Lavras (MG), from October to November, 2015. A prototype solar water heater was constructed using alternative materials - SASA, which was compared to three other heating systems (conventional solar water heater - SASC, infrared lamps - SALI and concrete floor heated by means of electric resistance (SAEL). The use of thermographic images allowed a greater accuracy in the measurements of sensible heat dissipation in piglets, showing variations during the first weeks of life, as well as in the different heating systems evaluated.
\end{abstract}

Keywords: Swine production, infrared thermography, images

\section{TEMPERATURA SUPERFICIAL DE LEITÕES EM ESCAMOTEADORES SUBMETIDOS A DIFERENTES SISTEMAS DE AQUECIMENTO}

\section{RESUMO}

Objetivou-se com o presente trabalho avaliar o bem-estar e a temperatura superficial de leitões submetidos a diferentes sistemas de aquecimento em escamoteadores durante as três primeiras semanas de vida, por meio da termografia infravermelha. Este trabalho foi realizado em uma maternidade de suínos do Centro Experimental em Suinocultura da Universidade Federal de 
Lavras (MG), no período de outubro a novembro de 2015. Para isto, foi construído um protótipo de aquecedor solar de água utilizando materiais alternativos - SASA, que foi comparando a três outros sistemas de aquecimento (aquecedor de água solar convencional - SASC, lâmpadas de infravermelho - SALI e piso concreto aquecido por meio de resistência elétrica (SAEL). Foram avaliados cinco animais de cada tratamento. Conclui-se que o uso de imagens termográficas permitiu maior acurácia nas medidas de dissipação de calor sensível em leitões, demonstrando variações durante as primeiras semanas de vida, bem como nos diferentes sistemas de aquecimento avaliados.

Palavras-chave: Suinocultura, termografia de infravermelho, imagens

\section{INTRODUCTION}

In swine, one of the problems related to thermal comfort and animal welfare is in the maternity, where there are two animal categories with well differentiated thermal requirements. The higher air temperature required for the thermal comfort of piglets is due to the fact that the young animals still have their thermoregulatory system underdeveloped, have a specific surface in contact with the relatively large environment, low energy reserve, and little insulation (SILVA et al., 2005).

The pigs lose heat mainly through the sensitive processes of conduction, convection and radiation. When subjected to caloric stress, the evaporative losses increase to compensate for the reduction of the sensible losses of heat (BAÊTA \& SOUZA, 2012).

In Brazil, due to the high temperatures that predominate most of the year, the loss by evaporation of water through the respiratory tract is the most effective form of heat loss, since the pigs have few functional sweat glands.

An infrared thermometer (also called an optical pyrometer) is a device that measures temperature without direct physical contact from which it is desired to know the temperature (NÄÄS et al., 2013). While infrared light is invisible to the human eye, infrared thermographic cameras have the function of identifying heat from the surface of an object and showing the user temperature information through visible colors. Several studies have used thermographic analysis to evaluate the heat dissipated by animals (KULESZA \& KACZOROWSKI, 2004; SILVA et al., 
2005; D'ALTERIO et al., 2011). However, few studies have been conducted to quantify the heat dissipation of piglets in different heating systems.

Infrared thermography has assumed, at an experimental level, an increasingly important role as a safe, non-invasive method useful for analysis in different areas such as the automobile industry, aeronautical industry, chemical industry, applications in civil engineering, animal production, and medicine.

Considering the enormous importance of the pig production chain in Brazil, the objective of this study was to evaluate the welfare and surface temperature of piglets by means of infrared thermography submitted to different heating systems in creep feeders during the first three weeks of animal life.

\section{MATERIAL AND METHODS}

\section{Maternity characterization}

The present work was carried out in a Pig Maternity Unit of the Experimental Center for the Swine Industry of the Federal University of Lavras, in the state of Minas Gerais, Brazil, latitude $21^{\circ} 14^{\prime} \mathrm{S}$, longitude $45^{\circ} 00^{\prime} \mathrm{W}$ and altitude $920 \mathrm{~m}$, with climate, according to Köeppen classification, classified as Cwa (temperate humid, with dry winter and rainy summer, subtropical, with dry winter and warmer month temperature higher than $22^{\circ} \mathrm{C}$ ), from October to November 2015, comprising a complete cycle of the piglets in the maternity.

The maternity evaluated in this study had the following construction characteristics: dimensions of $8.26 \mathrm{~m}$ wide and $8.40 \mathrm{~m}$ long, height to low point of roof of $2.15 \mathrm{~m}$, wall height of $0.85 \mathrm{~m}$ of height, roof in two waters, structured in wood and covered with ceramic roofing tiles. The walls were made of white ceramic brick. A ventilator / nebulizer was installed inside the maternity ward. Five bays, 1,80 $\mathrm{m}$ long and 1,35 $\mathrm{m}$ wide, were attached to the interior of the same, attached to wooden creep feeders with $1.00 \mathrm{~m}$ long by $0.68 \mathrm{~m}$ wide.

In this study five breeding cells were used, oriented in the center of each bay, lodging a sow in each cell. The breeding cells and the respective sows were selected randomly.

The piglets used in this study were from sows of the same order of childbirth. These animals were divided with the objective of eliminating factors of interference, maternal ability, number of pigs/pregnancy, etc. In each bay were 8 to 12 pigs which, after birth, were rearranged by criterion 
of weight and number of animals so that all the shelters studied had a number fixed between 8 and 12 piglets.

\section{Construction and characterization of heating systems}

In this study, the surface temperature was evaluated for floors heated by four different heating systems: a) creep feeder shelter equipped with a $250 \mathrm{~W}$ infrared lamp, fixed to the roof of the shelter, at a height of $0.50 \mathrm{~m}$ from the floor (SALI); b) creep feeder shelter equipped with concrete floor heated by means of hot water pipes constructed with alternative materials (SASA); c) creep feeder shelter equipped with concrete floor heated by means of conventional hot water pipes (SASC); and d) creep feeder shelter equipped with concrete floor heated by means of electric resistance (SAEL). Construction details of the treatments can be observed in the drawings shown in Figure 1.

(a)

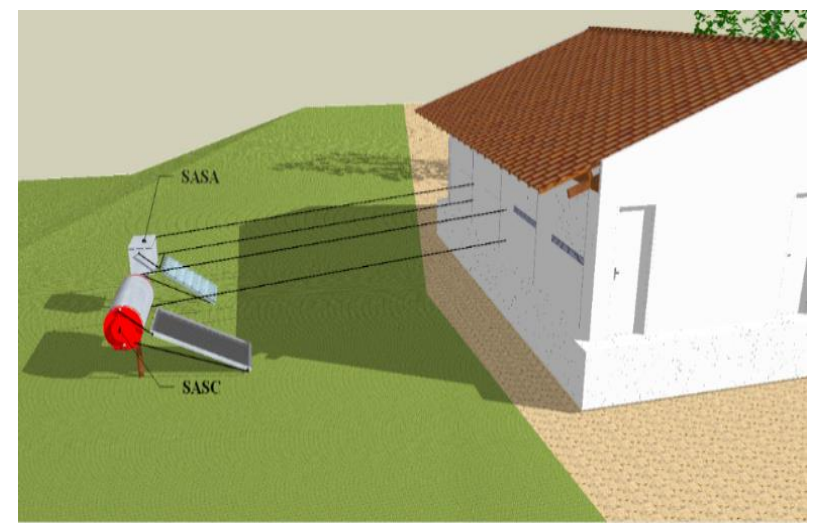

(b)

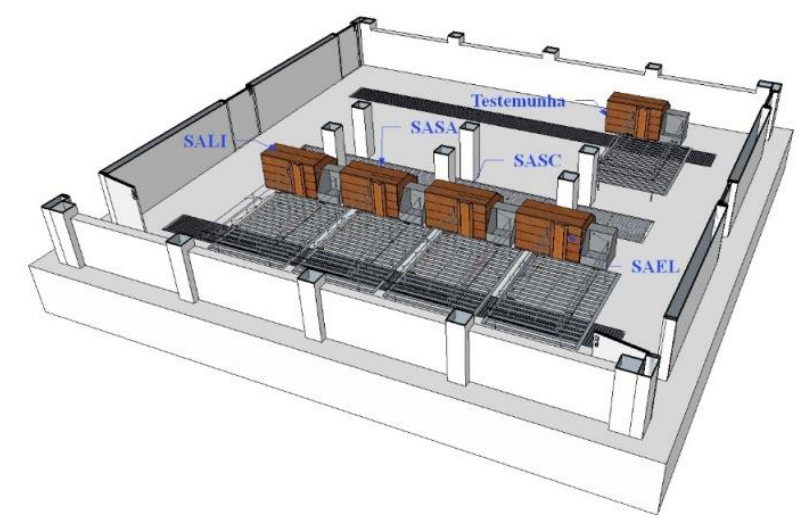

Figure 1. Schematic of the solar panels for heating the treatments SASA and SASC (a) and (b) distribution of treatments inside the maternity. Lavras - MG, 2015

The heating system present in each treatment tested was manually controlled, according to the management adopted by the farm, during the study period.

The conventional solar water heating system (SASC) had a glass plate solar collector, made of aluminum, with internal fins painted in matte black to absorb solar radiation and transfer to internal piping. The components of the thermal reservoir had internal cylinders and tubes made of stainless steel and rigid expanded polyurethane. 
The prototype solar water heaters manufactured with alternative material (SASA) were constructed with PVC pipes and fittings (1/2 "diameter), PET bottles and milk cartons (Tetra Pak $\left.{ }^{\circledR}\right)$. The Tetra-Pak ${ }^{\circledR}$ boxes were painted black-matte to absorb heat, and to maintain it inside the bottles so that it transfers to water through the PVC tubings, that were also painted black-matte.

In the construction of the prototype alternative solar heater, 60 bottles of transparent Polyethylene terephthalate (PET) of 2 liters were used. The Tetra Pak® boxes were opened on top and bottom, leaving them plane, using a cutter guide proposed by CELESC (2009) to keep a standard in all the boxes.

In the construction of the alternative hot water reservoir, a 50-liter fiberglass water box was used covered with Polystyrene plates $(30 \mathrm{~mm})$, Duct Tape and a self-adhesive asphalt aluminum blanket $(2,5 \mathrm{~mm})$ to protect the Polystyrene plates against the weather. In the reservoir, four holes were made of $20 \mathrm{~mm}$ each, two holes being for water circulation between the thermal reservoir and the solar collector and the other two holes for water circulation from the thermal reservoir to the floor.

To test the two water heating systems, two floors were constructed of mortar in the dimensions of length $74 \mathrm{~cm}$, width $46 \mathrm{~cm}$ and thickness $7 \mathrm{~cm}$. To reduce the dissipation of heat at the base of the floors $30 \mathrm{~mm}$ polystyrene, plates were used. $20 \mathrm{~mm}$ galvanized steel tubing was placed in each floor forming a coil, with the objective of uniformly distributing the heat of the water in the interior of the floor.

The two solar collectors and the water reservoirs were distanced from the maternity ward about $10 \mathrm{~m}$ to avoid shading (Figure 1). A low-flow water pump (model ZC-T40, 12V and 1.05A) was used in each system to force circulation of water in each system. In each floor, a microcontrolled digital controller (thermostat) designed for solar heating applications was used to control the circulation of water through the temperature differential between the entrance of the floor and the thermal reservoir.

\section{Measurement and instrumentation}

During all the stages of this study, the environmental variables were monitored in the shelter, in the internal environment and external to the maternity ward, by means of data acquisition systems (sensors / Data loggers), with automated registration, the following variables that compose 
the thermal environment: air dry bulb temperature $\left(\mathrm{T}_{\mathrm{bs}}\right)$, relative humidity $(\mathrm{RH})$ and velocity of air $\left(\mathrm{V}_{\text {air }}\right)$.

These environmental variables were recorded every 10 minutes, for 24 hours a day, during the first 21 days of the piglets' life, at a point allocated inside each shelter.

Sensors/Data loggers of $\mathrm{T}_{\mathrm{bs}}$ and $\mathrm{RH}\left(\mathrm{Hobo}^{\circledR}\right.$, mod. U12-012 and precision of $\pm 2.5 \%$ ) were mounted in the interior of a perforated protective container to prevent damage to the equipment caused by the pigs or excess of humidity. The readings were compared with another sensor external to the protective container, to verify any interference of the protection on the reading of the equipment. The air speed was measured manually by means of a hot-wire anemometer (Testo ${ }^{\circ}$, mod. 416 and resolution of $0.1 \mathrm{~m} \mathrm{~s}^{-1}$ ).

In the creep feeder shelters, the sensors/recorders were fixed in the cover at a distance of $0.5 \mathrm{~m}$ from the floor, approximately. In the maternity room, the ambient variables were registered in the interior of the installation, in the central region of the bays studied, at a height of $1.3 \mathrm{~m}$ from the floor, approximately. In the area external to the installations, the sensors/recorders which represent the microclimate of the location were installed in the interior of a meteorological shelter, at $1.5 \mathrm{~m}$ of height from the surface.

The temperatures of skin and floor surface were recorded using a thermographic camera (Instrutemp®, mod. ITTMV-100 and reading accuracy of $\pm 2 \%$ ). Surface temperatures were recorded in the morning (9:00 am to 11:00 p.m.) and afternoon (3:00 p.m. to 5 p.m.), daily during the first three weeks of life of the animals. The images were processed using the camera's own software, from 21 randomly selected points on each floor (Figure 2A). In the case of the animals inside the creep feeder, thermographic images were obtained covering the entire length of the animal (head, back, lumbar region, and leg), and 4 points were selected. The emissivity adopted was 0.95 (MONTANHOLI et al., 2008). 
(a)

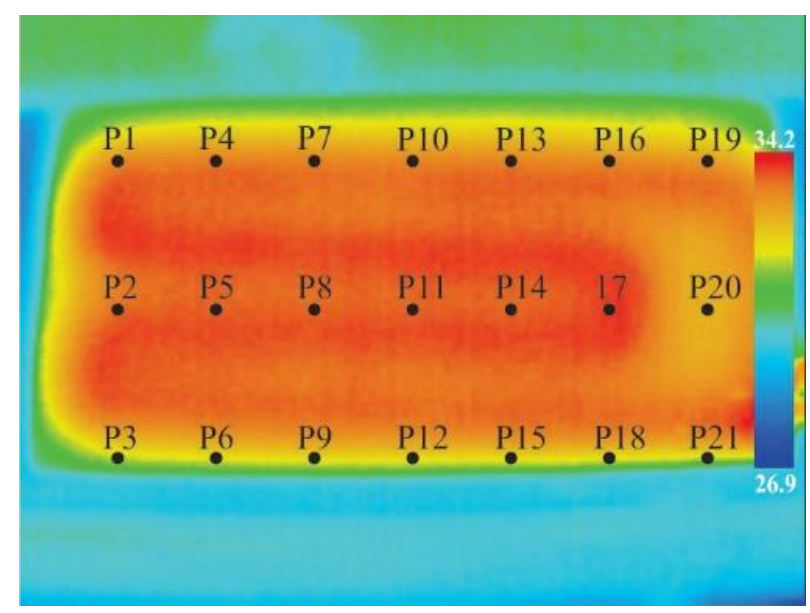

(b)

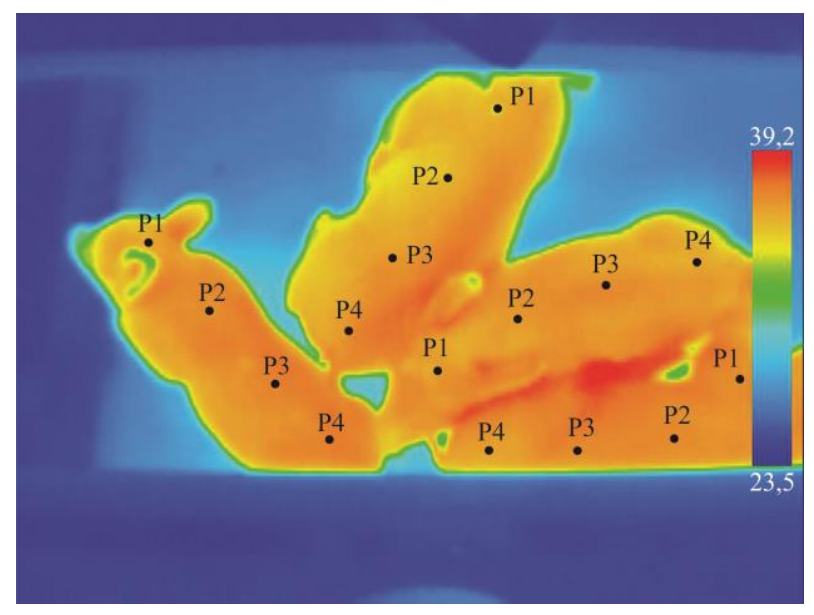

Figure 2. Thermographic images (a) of the heated concrete floor, and (b) the piglets inside the creep feeder. Lavras - MG, 2015

\section{Experimental design}

The experiment was set up in a randomized complete block design (DBC), with a factorial scheme 4 x 4, that is, 4 treatments and 4 weeks. Each evaluated week was considered as block. Three replicates were performed for each treatment. For variance analysis the parameters evaluated were processed by the statistical program Sisvar 4.6 (FERREIRA, 2011), being developed by the Federal University of Lavras.

\section{RESULTS AND DISCUSSION}

During the experimental period the $\mathrm{T}_{\mathrm{bs}}$ and internal mean $\mathrm{RH}$ of the maternity ward remained at $23.7 \pm 2.3{ }^{\circ} \mathrm{C}$ and $81.4 \pm 5.7 \%$, respectively. In addition, the mean values of $\mathrm{T}_{\mathrm{bs}}$ and RH external to the maternity were $32.1 \pm 2.3{ }^{\circ} \mathrm{C}$ and $77.0 \pm 4.9 \%$, respectively.

There was a significant difference between the mean values of $\mathrm{T}_{\mathrm{bs}}$ and $\mathrm{RH}$ (Tukey test, $\mathrm{p}$ $<0.05$ ) observed (Figure 3). The effect of the different heating systems on the $\mathrm{T}_{\mathrm{bs}}$ inside the creep feeder shelter was observed (Figure 3A). It was found that only the SALI heating system remained most of the time within the comfort range for piglets, which is $29{ }^{\circ} \mathrm{C}$ to $34{ }^{\circ} \mathrm{C}$ (LOSSEC et al., 1998; RENAUDEAU et al., 2003; JOHNSON \& MARCHEANT-FORDE, 2009). In this case, the mean $\mathrm{T}_{\mathrm{bs}}$ of the SALI system was $37.6 \pm 3.6^{\circ} \mathrm{C}$. On the other hand, the piglets present in the other treatments (SASA, SASC and SAEL) were susceptible to cold thermal stress. In view of these 
results, it is evident that improvement in heating systems is required to maintain the thermal comfort conditions within the creep feeder housing.

Silva et al. (2005), when evaluating the behavior of piglets in different maternity warming systems, mention that in relation to the infrared lamp, the $\mathrm{T}_{\mathrm{bs}}$ data inside the shelter were, on average, always above the ideal condition, throughout all experimental phases.

The variation of the RH within the shelters had significant differences (Tukey test, $\mathrm{p}<0.05$ ), mainly in the heating system with infrared lamp (SALI), which besides promoting high $\mathrm{T}_{\mathrm{bs}}$, significantly reduced RH inside (Figure 3B). In the SASA, SASC and SAEL treatments, the RH presented closer to ideal values between 60 and 70\% (NÄ̈̈S, 1989; SILVA, 1999). The maximum difference of the RH average between the indoor environment of the shelter and the maternity ward did not exceed 14\%. The radiant heat energy of the heated floors in the SASA, SASC and SAEL treatments was not sufficient to promote the reduction of $\mathrm{RH}$ inside the creep feeder's shelter, presenting values close to the RH of the maternity ward.

(a)

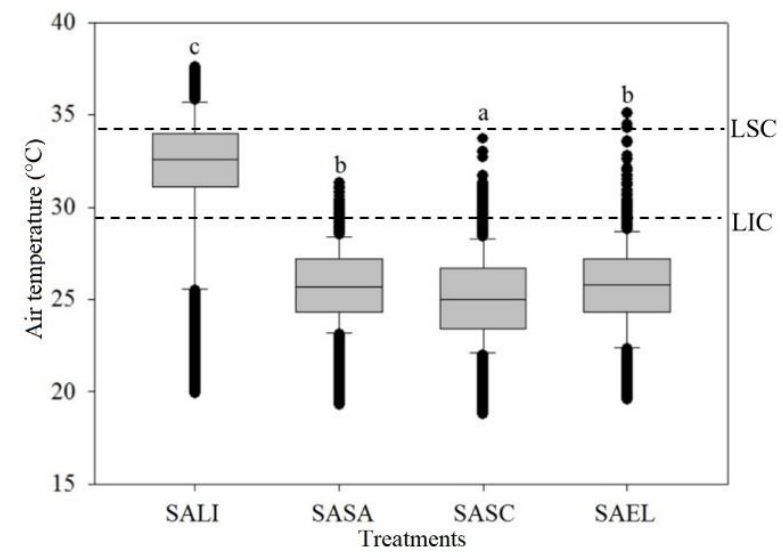

(b)

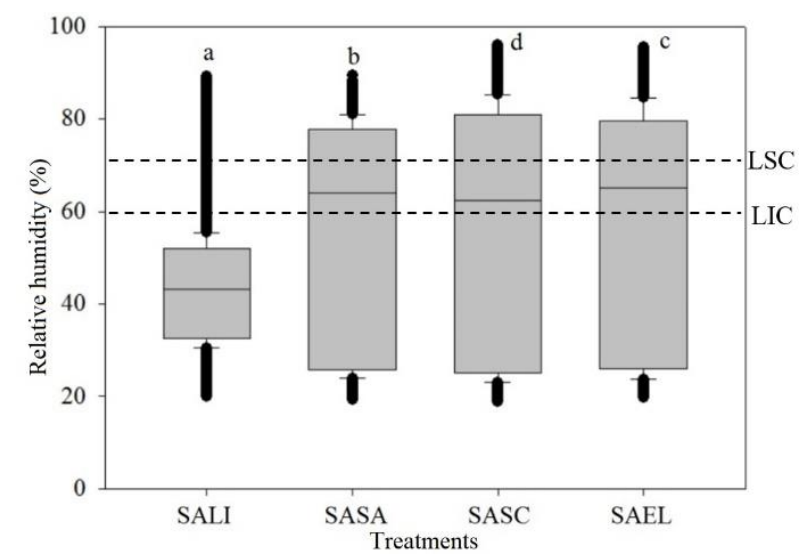

Figure 3. Mean values of (a) air temperature and (b) relative humidity in the indoor environments of the creep feeder in the treatments evaluated. The averages followed by equal letters, in the same column, do not differ statistically from each other, by the Tukey test, at 5\% probability. LSC - upper comfort limit and LIC - Lower comfort limit. Lavras - MG, 2015.

Traditionally, infrared lamps have been used in a localized way in the creep feeder, with the objective of guaranteeing the thermal comfort to the piglets, not covering the full extent of the area of the lactation bay. This fact can imply high consumption of electrical energy and an area providing limited thermal comfort. Thus, within the principles of thermal comfort and animal 
welfare, there is a need for individualized attention to the piglets, in order to protect them from exposure to temperatures outside their comfort range, which means investing in low-cost and high efficiency heating systems (SILVA et al., 2005).

The data referring to the average values found for the surface temperature of the floors inside the creep feeder shelters were registered (Table 1).

Table 1. Means and standard deviation of the surface temperatures of the floors inside the creep feeder in the morning and afternoon periods, submitted to different heating systems. Lavras - MG, 2015

\begin{tabular}{llllllllllllll}
\hline \multicolumn{1}{l}{ Floor surface temperature means by treatment $\left({ }^{\circ} \mathbf{C}\right)$} \\
\hline Period & SALI & \multicolumn{3}{c}{ SASA } & \multicolumn{1}{c}{ SASC } & \multicolumn{3}{c}{ SAEL } \\
\hline Morning & 33.6 & \pm & $2.6 \mathrm{~d}$ & 30.0 & \pm & $2.5 \mathrm{~b}$ & 28.3 & \pm & $0.8 \mathrm{a}$ & 32.6 & \pm & $3.1 \mathrm{c}$ \\
\hline Afternoon & 33.0 & \pm & $2.5 \mathrm{~b}$ & 31.6 & \pm & $1.7 \mathrm{a}$ & 33.3 & \pm & $0.9 \mathrm{c}$ & 33.9 & \pm & $1.8 \mathrm{~d}$ \\
\hline
\end{tabular}

The averages followed by equal letters, in the same column, do not differ statistically from each other, by the Tukey test, at $5 \%$ probability.

There was treatment effect on the surface temperature of the floors in both periods evaluated (Tukey test, $\mathrm{p}<0.05$ ). In the morning, it was observed that the highest mean surface temperature of the floor occurred in the SALI treatment, on the other hand, in the afternoon, in the SAEL treatment. In general, the afternoon averages were higher than the morning periods, differing only from the SALI treatment, where a minimum variation was observed.

During the morning the floor surface temperature in the SASA and SASC treatments were lower than $29{ }^{\circ} \mathrm{C}$ during $73 \%$ of the evaluated period, whereas in the SALI treatment much of the time (27\%) it was between 33 and $35^{\circ} \mathrm{C}$ (Figure 4). Although the differences were low, the mean frequency distribution of floor temperature for the morning period remained with most values within the comfort range only in the SALI and SAEL treatments.

However, for the SASA, SASC and SAEL treatments, in the afternoon, most of the surface temperature values of the floor were between $33{ }^{\circ} \mathrm{C}$ and $35{ }^{\circ} \mathrm{C}$ (Figure 5). The best temperature frequency distribution was observed in the SALI treatment (Figure 5A). 
(a)

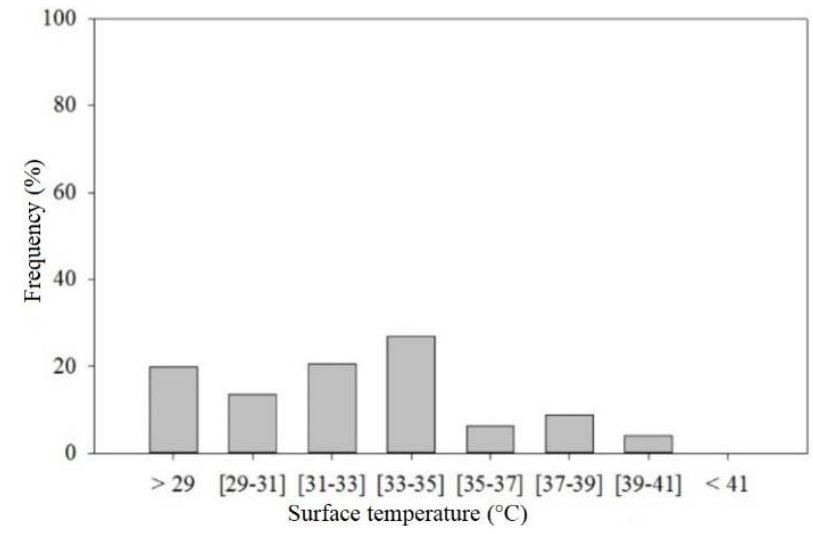

(c)

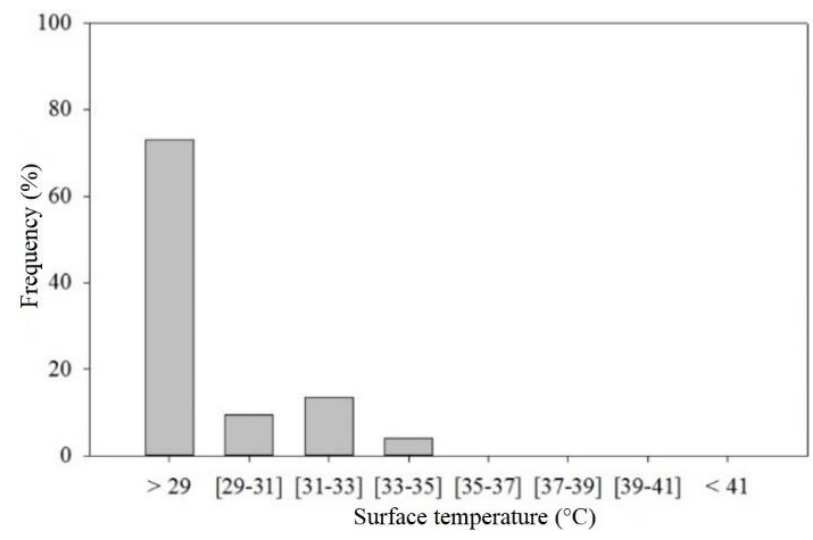

(b)

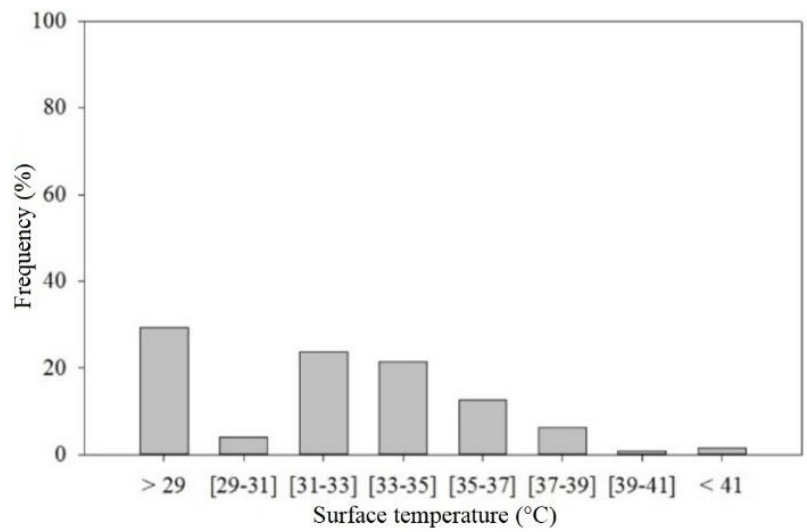

(d)

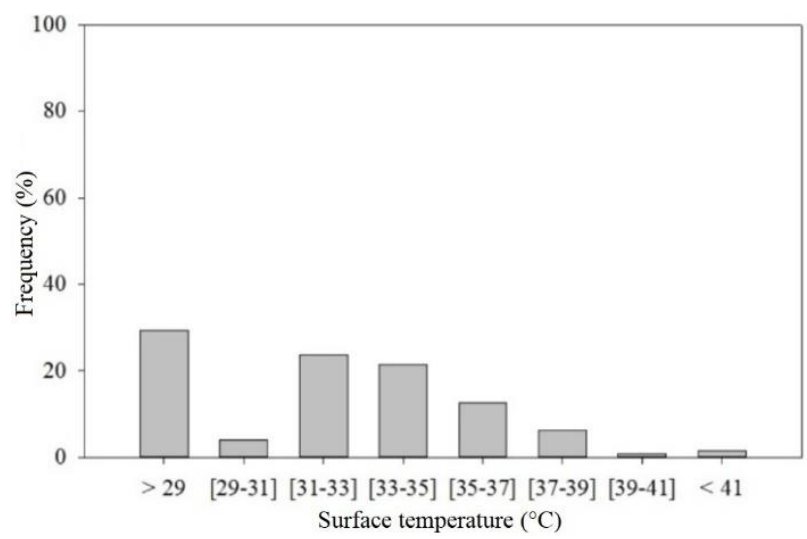

Figure 4. Frequencies $(\%)$ of the surface temperature means of the heated floors during the morning (9:00 a.m. to 11:00 a.m.) in the treatments: (a) SALI, (b) SASA, (c) SASC, and (d) SAEL. Lavras - MG, 2015

Mean floor temperatures lower than $29^{\circ} \mathrm{C}$ are a risk for the survival of piglets, especially in the first days of life, because thermoregulatory capacity is still not well developed at birth and therefore they are subject to cold stress (LOSSEC et al., 1998).

Most of the researches with different heating systems for pigs (McGINNIS et al., 1981; SILVA et al., 2005, SABINO et al., 2015) have shown significant results in the use of heated floors due to the heat transfer by conduction from the floor to the animals, being a more thermally efficient method.

Currently, there is a wide range of floor heater types on the market. However, the model with longer durability, cost benefit, meeting the requirements of sustainable or green product can be a great alternative for replacing the lamps. In order to make the heating system feasible, recycled 
products can be used as an alternative to promote the thermal comfort temperature for piglets in a sustainable way, especially from an ecological and economic point of view.

Sartor et al. (2015) used Tetra Pak® as a thermal insulation in the covering of creep feeders and kept the room temperature comfortable $\left(32^{\circ} \mathrm{C}\right)$, superior to the shelters without the covering, providing greater thermal comfort to the suckling piglets, making the heating process more efficient.

(a)

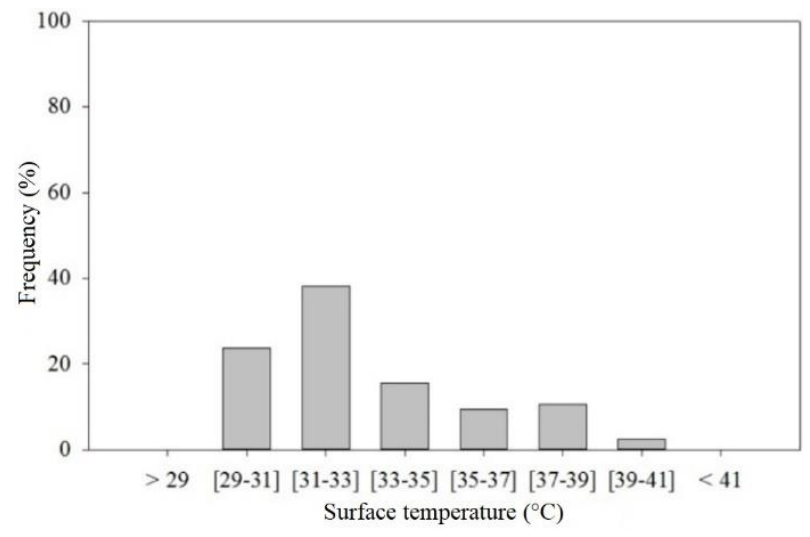

(c)

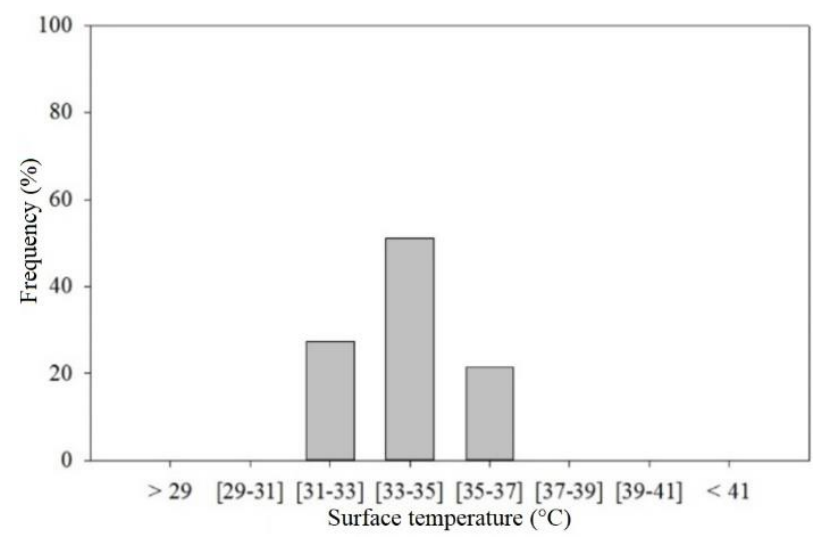

(b)

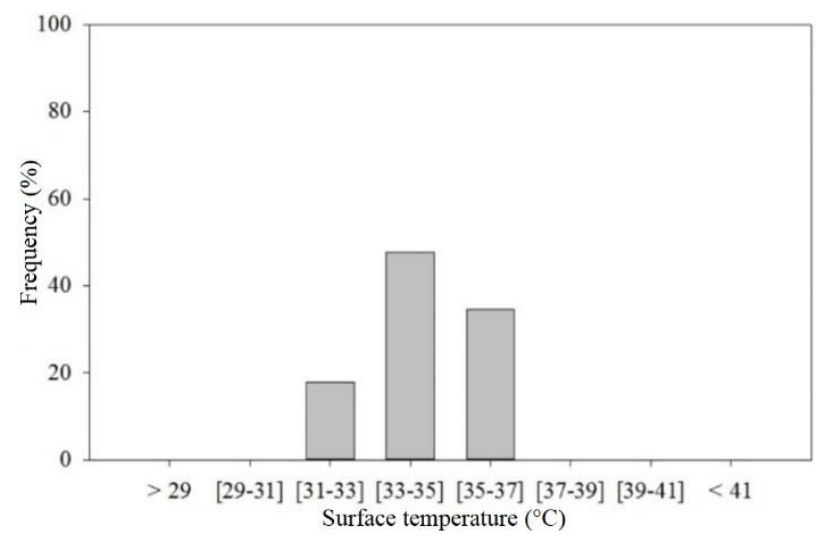

(d)

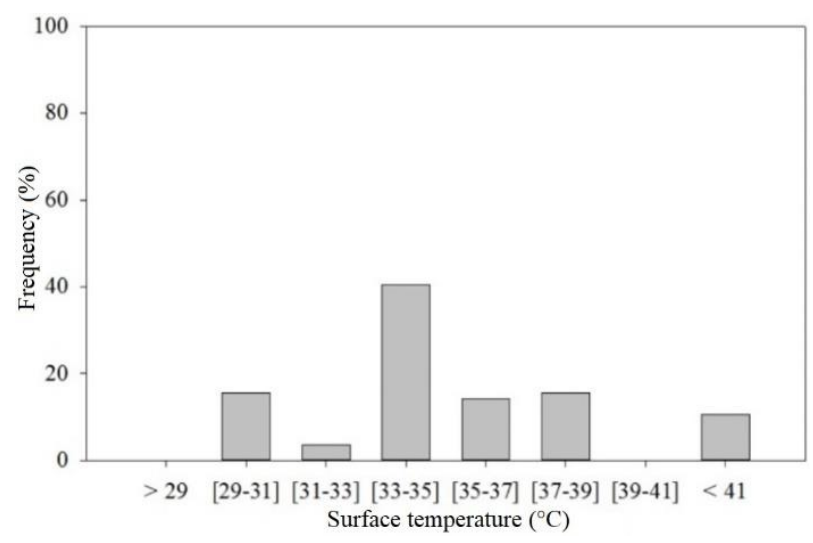

Figure 5. Frequencies $(\%)$ of the surface temperature means of the heated floors during the afternoon (15:00 a.m. to 5:00 p.m.) in the treatments: (a) SALI, (b) SASA, (c) SASC, and (d) SAEL. Lavras - MG, 2015

Table 2 shows the mean values and standard deviations compared by the Tukey test (5\%) of the mean superficial skin temperature of the piglets for the different treatments tested during the morning and afternoon. 
Table 2. Means and standard deviation of the surface temperatures of the piglets in the interior of the farmer in the morning and afternoon, submitted to different heating systems. Lavras - MG, 2015

Average surface temperature of floors by treatment $\left({ }^{\circ} \mathrm{C}\right)$

\begin{tabular}{lllllllllllll}
\hline Period & SALI & \multicolumn{3}{c}{ SASA } & \multicolumn{3}{c}{ SASC } & \multicolumn{3}{c}{ SAEL } \\
\hline Morning & 37.3 & \pm & $0.5 \mathrm{~b}$ & 37.1 & \pm & $1.2 \mathrm{a}$ & 37.4 & \pm & $0.6 \mathrm{c}$ & 38.8 & \pm & $1.9 \mathrm{~d}$ \\
\hline Afternoon & 37.6 & \pm & $0.8 \mathrm{~b}$ & 37.4 & \pm & $1.1 \mathrm{a}$ & 37.7 & \pm & $0.8 \mathrm{c}$ & 39.2 & \pm & $1.0 \mathrm{~d}$ \\
\hline
\end{tabular}

The averages followed by equal letters, in the same column, do not differ statistically from each other, by the Tukey test, at $5 \%$ probability.

There was a significant difference between the mean superficial temperatures of the piglets in the different heating systems tested (Tukey test, $\mathrm{p}<0.05$ ). The mean surface temperature of the piglets' skin showed an increase in the evening period, probably due to the increase of heat during the afternoon. It was observed that, during the evaluated period, the surface temperature of the animals was higher in the SAEL treatment. On the other hand, the lowest surface temperature of the animals was observed in the SASA treatment. The maximum variation of the surface temperature of the piglets between the treatments tested for both evaluated periods (morning and afternoon) was $1.7^{\circ} \mathrm{C}$.

In all treatments with solar heating (SASA and SASC), most of the piglet surface temperature values in the morning were between 35 and $37{ }^{\circ} \mathrm{C}$ (Figure 6). On the other hand, in the SALI and SAEL treatments, the highest frequency was observed in the surface temperature range of piglets of 37 and $39^{\circ} \mathrm{C}$.

In the afternoon, $80 \%$ of the surface temperature values of the piglets observed were between 37 and $39^{\circ} \mathrm{C}$ in the SALI treatment (Figure 7). In the SAEL treatment, 53.8\% of the values were between 39 and $41{ }^{\circ} \mathrm{C}$. Ferreira et al. (2007), observing the surface temperature of piglets during the first $24 \mathrm{~h}$ of life, found mean values close to $37^{\circ} \mathrm{C}$.

Panzardi et al. (2009) demonstrated that body temperature at $24 \mathrm{~h}$ post-birth $\left(<38{ }^{\circ} \mathrm{C}\right)$ and birth order (>9) are the best indicators of survival rate during the first postnatal week.

According to FERREIRA et al. (2007), newborn piglets have a small capacity to regulate their body temperature, mainly because of their incomplete hypothalamic development, and it is essential to use supplementary sources of heat at this stage. 
(a)

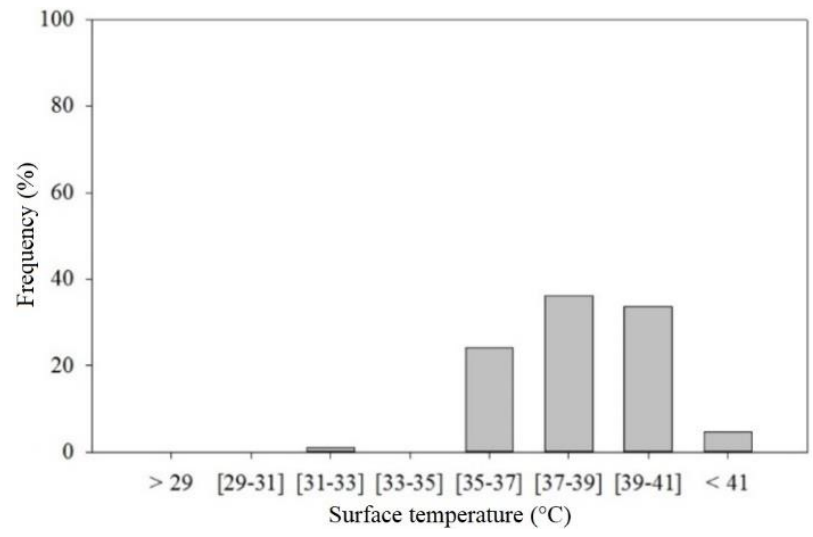

(c)

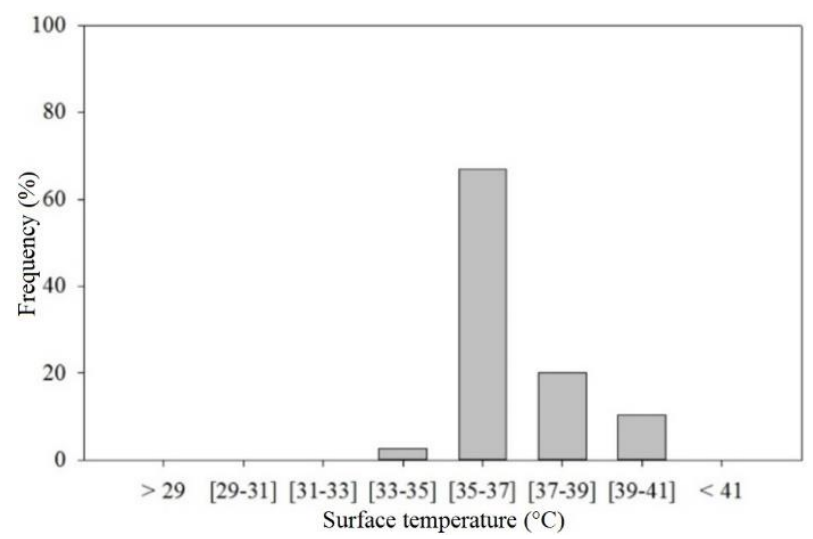

(b)

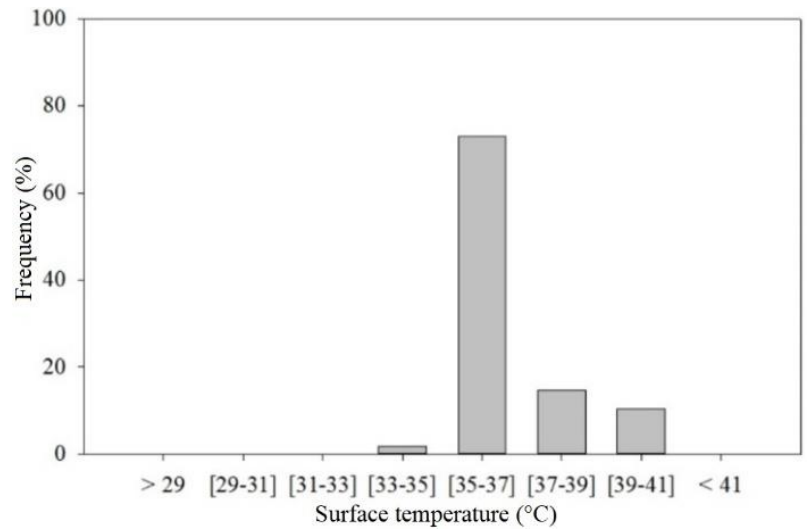

(d)

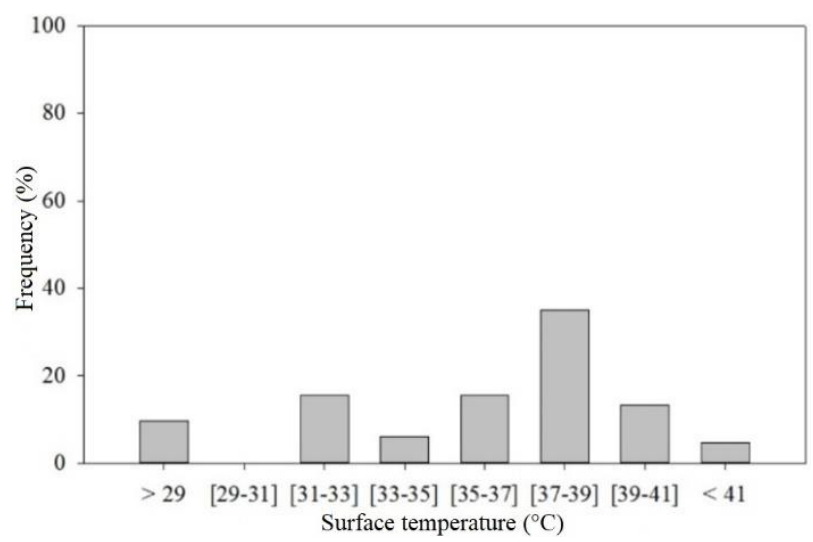

Figure 6. Frequencies (\%) of the surface temperature means of the animals during the morning (9:00 a.m. to 11:00 a.m.) in the treatments: (a) SALI, (b) SASA, (c) SASC, and (d) SAEL. Lavras - MG, 2015

Keeping the sows and piglets in their thermal comfort zones in conventional maternities is a challenge, even in thermally controlled environments, due to the comfort temperature of the sows being located in the range of $22^{\circ} \mathrm{C}$ (QUINIOU \& NOBLET, 1999), while the piglets is within the range from $29^{\circ} \mathrm{C}$ to $34^{\circ} \mathrm{C}$ (LOSSEC et al, 1998; RENAUDEAU et al., 2003; JOHNSON \& MARCHANT-FORDE, 2009). While in sows, caloric stress has negative behavioral, physiological and productivity consequences (QUINIOU \& NOBLET, 1999; RENAUDEAU et al., 2001), in piglets with a drop in body temperature from $2^{\circ} \mathrm{C}$ to $4^{\circ} \mathrm{C}$ during the birth period, if a sufficient heat source is not provided, a hypothermia condition may occur, reducing vigor and milk intake, and eventually leading to death (LOSSEC et al., 1998). 
(a)

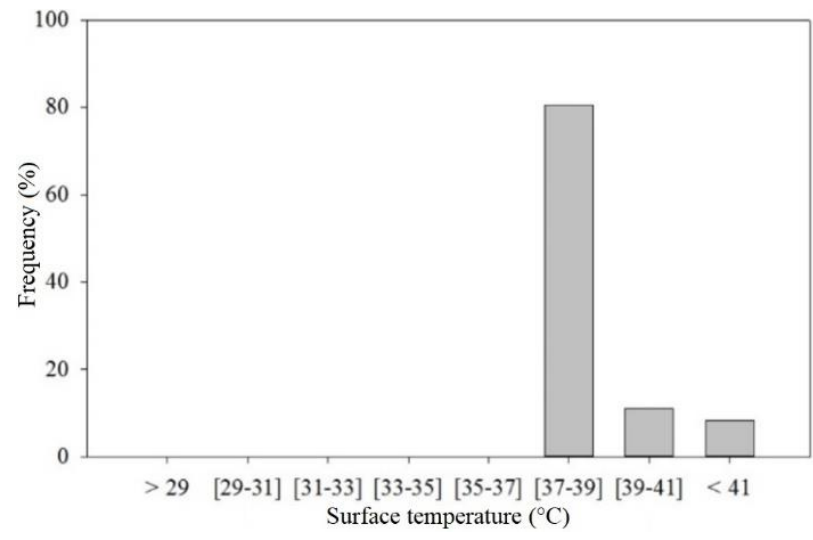

(c)

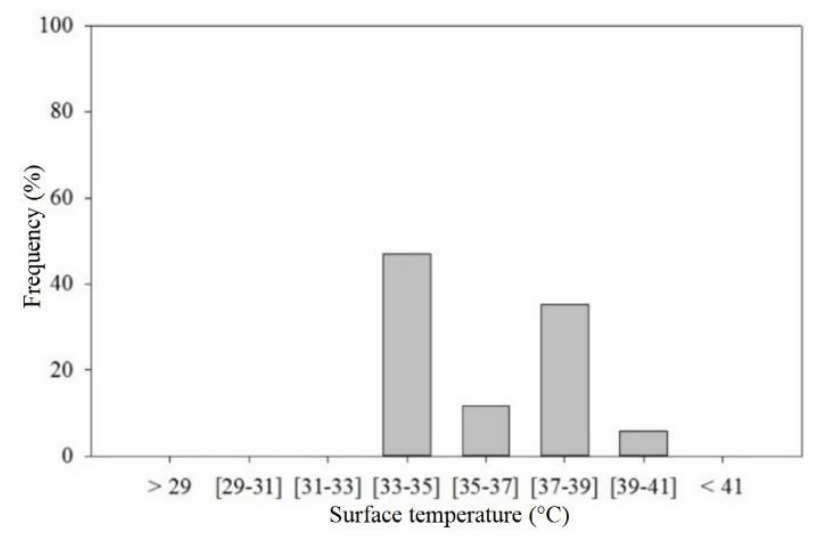

(b)

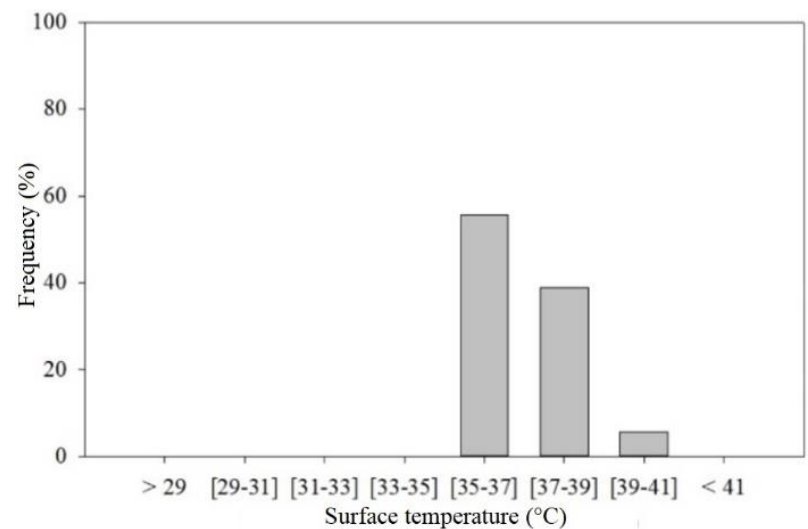

(d)

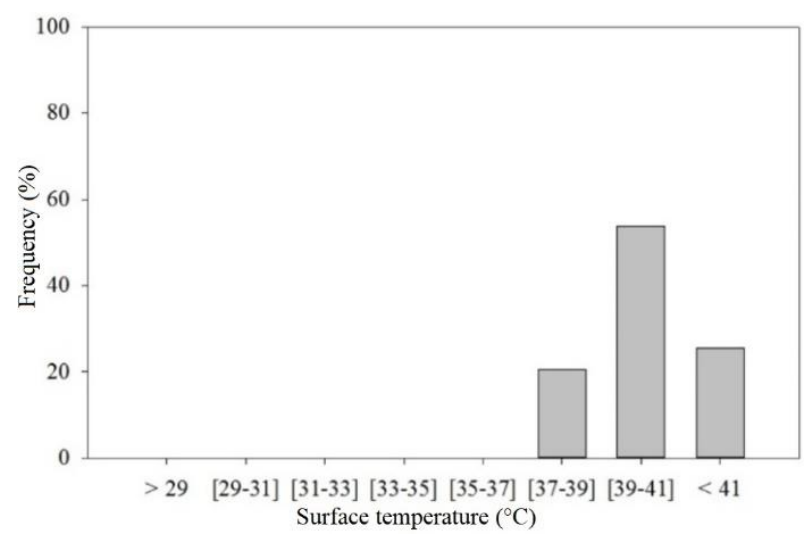

Figure 7. Frequencies $(\%)$ of the surface temperature means of the animals during the afternoon (15:00 h to 17:00 h) in the treatments: (a) SALI, (b) SASA, (c) SASC e (d) SAEL. Lavras $-\mathrm{MG}, 2015$

\section{CONCLUSIONS}

Based on the results, it was verified that the use of the different heating systems used is not efficient to maintain the environmental conditions inside the creep feeder shelters, within the thermal comfort limits of the piglets in the first two weeks of life of the animals. On the other hand, in almost all treatments tested, the heating system is efficient at maintaining the temperature of the floors at the comfort limit of the animals, which can be proven with the use of thermographic images. Thus, the use of thermographic images allows a greater accuracy in the measurements of sensible heat dissipation in piglets, showing variations during the first weeks of life, as well as in the different heating systems evaluated. 


\section{ACKNOWLEDGEMENTS}

To the Coordination for Improvement of Higher Education Personnel (CAPES), the National Council for Scientific and Technological Development (CNPq) and the Foundation for Research Support of the State of Minas Gerais (FAPEMIG) for the financial support of the project.

\section{REFERENCES}

BAÊTA, F. C.; SOUZA, C. F. 2012. Ambiência em edificações rurais: Conforto animal. Viçosa: Editora UFV, $2^{a}$ ed. 269p.

CELESC. 2009. Aquecedor solar composto de produtos descartáveis - Manual de construção e instalação. Florianópolis: Governo do Estado de Santa Catarina, 44 p.

D'Alterio G., CASElla S., GATTO M., GIANESELlA M., PICCIONE G., MORGANTE M. 2011. Circadian rhythm of foot temperature assessed using infrared thermography in sheep. Czech Journal Animal Science, Slezská 7, v. 56, p. 293-300.

FERREIRA, D. F. 2011. Sisvar: a computer statistical analysis system. Ciência e Agrotecnologia, Lavras, v.35, n.6, p.1039-1042.

FERREIRA, R. A.; CHIQUIERI, J.; MENDONÇA, P. P.; MELO, T. V.; CORDEIRO, M. D.; SOARES, R. T. R. N. 2007. Comportamento e parâmetros fisiológicos de leitões nas primeiras 24 horas de vida. Ciência e Agrotecnologia, Lavras, v. 31, n. 6, p. 1845-1849.

JOHNSON, A. K.; MARCHANT-FORDE, J. N. 2009. Welfare of Pigs in the Farrowing Environment. The Welfare of Pigs. Springer Netherlands, Dordrecht, v. 7, p. 141-188.

KULESZA, O.; KACZOROWSKI, M. 2004. Thermography and its practical use in equine diagnostics and treatment. Medycyna Weterynaryjna, Lublin, v. 60, n. 11, p. 1143-1146.

LAUREANO, D. F.; SIMON, L. B.; GROSSPOKOPF, R. K.; LIMA, J.; OLTRAMARI, C. E.; NUNES, M. L. A.; MÜLLER, L. K. F. 2014. Avaliação fisiológica de leitões em diferentes sistemas de aquecimento de escamoteador. In: XXIV Congresso Brasileiro de Zootecnia, 2014, Vitória, Anais...Vitória: Sociedade Brasileira de Zootecnia. Vitória - ES.

LOSSEC, G.; HERPIN, P.; Le DIVIDICh, J. 1998. Thermoregulatory Responses of the Newborn Pig during Experimentally Induced Hypothermia and Rewarming. Experimental physiology, Londres, v. 83, n. 5, p. 667-678.

MONTANHOLI, Y.R.; ODONGO, N. E.; SWANSON, K. C.; SCHENKEL, F. S.; McBRIDE, B. W.; MILLER, S. P. 2008. Application of infrared thermography as an indicator heat and methane production and its use in the study of skin temperature in response to physiological events in dairy cattle (Bos taurus). Journal of Thermal Biology, Ontario, v. 33, p. 468-475.

McGINNIS, R. M.; MARPLE, D. N.; GANJAM, V. K.; PRINCE, T. J.; PRITCHETT, J. F. 1981. The effects of floor temperature, supplemental heat and drying at birth on neonatal swine. $\mathbf{J}$ ANIM SCI, Champaign, v. 53, p. 1424-1431.

NÄÄS, I. A.; GARCIA, R. G.; GRACIANO, D. E.; SANTANA, M. R.; CALDARA, F. R. 2013. Temperatura superficial de porcas em lactação submetidas ao resfriamento adiabático. Enciclopédia Biosfera - Centro Científico Conhecer, Goiânia, v. 9, n. 16, p. 2007-2013.

NÄ̈̈S, I.A. 1989. Princípios de conforto térmico na produção animal. São Paulo: Ícone, $1^{\mathrm{a}}$ ed. $183 p$. 
PANZARDI, A.; MARQUES, M. F. P. P; HEIM, G.; BORTOLOZZO, F. P.; WENTZ, I. 2009. Fatores que influenciam o peso do leitão ao nascimento. Acta Scientiae Veterinariae, Porto Alegre, n. 37, v. 1, p. 49-60.

QUINIOU, N.; NOBLET, J. 1999. Influence of High Ambient Temperatures on Performance of Multiparous Lactating Sows. Journal of Animal Science, Champaign, v. 77, p. 2124-2134.

RENAUDEAU, D.; NOBLET, J.; DOURMAD, J. Y. 2003. Effect of Ambient Temperature on Mammary Gland Metabolism in Lactating Sows. Journal of Animal Science, Champaign, v. 81, p. 217-231.

RENAUDEAU, D.; NOBLET, J. 2001. Effects of Exposure to High Ambient 440 Temperature and Dietary Protein Level on Sow Milk Production and Performance of Piglets. Journal of Animal Science, Champaign, v. 79, p. 1540-1548.

SABINO, L. A.; ABREU, P. G.; SOUSA JR, V. R.; ABREU, V. M. N.; COLDEBELLA, A. 2015. Construction Material Interference on Air Temperature and Humidity Inside the Piglet Creep Area. Energia na Agricultura, Botucatu, v. 30, n. 4, p. 338-343.

SARTOR, K.; SARUBBI J.; LAZZARI R.; SOUZA S.; PAIM R. W.; MEDEIROS, B. B. L. 2015. Utilização de embalagens Tetra $\mathrm{Pak}^{\circledR}$ como isolante térmico no revestimento de escamoteadores para leitões. Arquivo Brasileiro de Medicina Veterinária e Zootecnia, Belo Horizonte, v. 67, n. 5, p. 1449-1456.

SILVA, I. J. O.; PANDORFI, H.; PIEDADE, S. M. S. 2005. Uso da zootecnia de precisão na avaliação do comportamento de leitões lactentes submetidos a diferentes sistemas de aquecimento. Brazilian Journal of Animal Science, Viçosa, MG, v. 34, n. 1, p. 220-229.

SILVA, I. J. O. 1999. Qualidade do ambiente e instalações na produção industrial de suínos. In: SIMPÓSIO INTERNACIONAL DE SUINOCULTURA, São Paulo, 1999, São Paulo. Anais... São Paulo: Gessuli, p. 108-325.

Received in: October 29, 2016 Accepted in: April, 24, 2019 